\title{
Q-L-RHAMNOSIDASE ACTIVITY OF ANTARCTIC STRAIN OF PSEUDOMONAS MANDELII U1
}

\author{
O.V. Gudzenko, N.V. Borzova, L.D. Varbanets \\ Zabolotny Institute of Microbiology and Virology, NAS of Ukraine, \\ 154 Acad. Zabolotny Str., Kyiv, 03143, Ukraine \\ e-mail:ov_gudzenko@bigmir.net
}

In recent years, cold-adapted enzymes are increasingly used in industrial processes such as the food, textile and beverage industries. Moreover, cold-active enzymes are usually thermolabile and can be inactivated with little heat. This is especially important in reactions where it is necessary to inactivate an enzyme after it has completed its function, while maintaining conditions that allow other enzymes involved in the reaction to function. Among these enzymes, glycosidases play an important role, which are used in medical technological processes, the food industry, biotechnology for the purification and processing of raw materials, as well as in many other areas of human activity. Therefore, the aim of this work was to study the ability of the psychrotolerant bacterium Pseudomonas mandelii U1 to produce glycosidases, in particular a-L-rhamnosidases, and also to investigate their physicochemical properties and substrate specificity. Methods. Glycosidase activities were determined by Romero and Davis methods, protein - by Lowry method. Results. The study of enzymatic activities in the dynamics of growth indicates that already on the third day of cultivation in the supernatant of the culture liquid of P. mandelii UI $\alpha$-L-rhamnosidase activity (0.09 U/mg protein) was noted. On the fifth day of cultivation, in addition to $\alpha$-L-rhamnosidase (0.09 U/mg protein), $\beta$-D-glucosidase (0.09 U/mg protein) and $\alpha$-D-glucosidase (0.09 U/mg protein) activities were identified. On the seventh and ninth days of cultivation, the spectrum of glycosidase activities was wider, except for $\alpha$-L-rhamnosidase (0.2 and $0.16 \mathrm{U} / \mathrm{mg}$ protein, respectively), $\beta$-D-glucosidase (0.02 and $0.05 \mathrm{U} / \mathrm{mg}$ protein, respectively) and $\alpha$-D-glucosidase $(0.04$ and $0.08 \mathrm{U} / \mathrm{mg}$ of protein, respectively), $\alpha$-D-mannosidase ( 0.025 and $0.025 \mathrm{U} / \mathrm{mg}$ protein, respectively), $\alpha$ - $D$-fucosidase (0.025 and $0.05 \mathrm{U} / \mathrm{mg}$ protein, respectively), $N$-acetyl- $\beta$-D-glucosaminidase $(0.025$ and $0.025 \mathrm{U} / \mathrm{mg}$ protein, respectively) and $N$-acetyl- $\beta$-D-galactosaminidase ( 0.025 and $0.025 \mathrm{U} / \mathrm{mg}$ protein, respectively). Since among the studied glycosidase activities, $\alpha$-L-rhamnosidase was the highest, subsequent studies were aimed at investigating its properties. It was shown that P. mandelii U1 $\alpha$-L-rhamnosidase has the $p H$ optimum of action at 5.0, and the temperature optimum - at $4{ }^{\circ} \mathrm{C}$. Conclusions. The temperature optimum of P. mandelii U1 $\alpha$-L-rhamnosidase preparation isolated from moss in Antarctica, Galindez Island, is $4{ }^{\circ} \mathrm{C}$, the optimum $\mathrm{pH}$ is 5.0, the enzyme is able to hydrolyze as synthetic substrates p-nitrophenyl- $\alpha$ $L$-rhamnopyranoside, $p$-nitrophenyl- $\beta$-D-glucopyranoside, $p$-nitrophenyl- $\alpha$-D-glucopyranoside, $p$-nitrophenyl- $\alpha$-D-mannopyranoside, and natural substrates - naringin, neohesperidin and rutin, which suggests the possibility of its use in the future in food technologies, in particular in food processing and waste degradation at low temperatures.

Keywords: Pseudomonas mandelii U1, $\alpha$-L-rhamnosidase, physicochemical properties, substrate specificity.

The Antarctic is one of the most extreme terrestrial environments inhabited by microorganisms [1]. This continent is notably marked by conditions of intense cold, low nutrient availability, strong winds [2], periods of high solar radiation and extended total darkness [3, 4], low atmospheric humidity, little water availability, and high salinity levels in dry valleys $[1,3]$. These physicochemical conditions impose thermodynamic and kinetic limits that, together with the oligotrophic character of the continent, represent real constraints for the development of biological communities. Indeed, optimum growth conditions are restricted for the majority of microorganisms described to date [3]. Until recently, it was believed that bacteria found in Antarctic were exclusively psychrophilic, but more and more psychrotolerant organisms are being reported from the soils, lakes, sediments, seawater, etc. of Antarctica, further corroborating the great diversity of microorganisms that exist on this continent $[5,6]$. This is due to the fact that psychrotolerant microorganisms use more 
survival strategies in the face of sharp seasonal changes in Antarctica than psychrophilic analogs [7]. The survival strategies of psychrotolerant microorganisms have been evolutionarily selected and have genetically and physiologically forged these microorganisms $[2,7]$. Ultimately, these survival strategies are of biotechnological interest, especially in relation to cold-adapted organisms [8]. Consequently, the Antarctic continent has become a focal point for obtaining new psychrophilic and psychrotolerant strains. The bacterial strains found to date in Antarctica include members of the Pseudomonas genus, one of the most successful and ubiquitous bacterial groups worldwide [8]. Recently, a new species of Pseudomonas Pseudomonas mandelii U1, was isolated in the Antarctic, which is a representative of psychrotrophic microorganisms [9], the properties of lipopolysaccharide of which were studied by us earlier [10].

Since in cold ecosystems bacteria play a vital role in biochemical cycles and biodegradation of waste, in recent years, researchers have paid great attention to the identification of the enzymes they synthesize. Since these enzymes exhibit high catalytic efficiency at low to moderate temperatures compared to their mesophilic and thermophilic homologues, they can provide significant economic benefits as their use leads to energy savings. Only a small amount of enzyme is required for effective catalysis at low temperatures. Coldadapted enzymes are increasingly used in industrial processes such as the food, textile and beverage industries. Moreover, cold-active enzymes are usually thermolabile and can be inactivated with little heat. This is especially important in reactions where it is necessary to inactivate an enzyme after it has completed its function, while maintaining conditions that allow other enzymes involved in the reaction to function.

Among these enzymes, glycosidases play an important role, which are used in medical technological processes, the food industry, biotechnology for the purification and processing of raw materials, as well as in many other areas of human activity.

Therefore, the aim of this work was to assess the ability of the psychrotolerant bacterium Pseudomonas mandelii $\mathrm{U} 1$ to produce glycosidases, in particular, $\alpha$-L-rhamnosidases, as well as to investigate their physicochemical properties and substrate specificity.
Materials and methods. The object of the study was the culture of Pseudomonas mandelii U1 [11], isolated from moss on Galindez Island in Antarctica and kindly provided to us for research by the staff of the Department of Extremophilic Microorganisms of the Zabolotny Institute of Microbiology and Virology, National Academy of Sciences of Ukraine.

To identify glycosidase activities, the cultivation of Pseudomonas mandelii was carried out under submerged conditions in flasks containing $100 \mathrm{~mL}$ of a nutrient medium of the following composition, $\mathrm{g} / \mathrm{L}$ : rhamnose $-4 ; \mathrm{NaNO}_{3}-2.0 ; \mathrm{KH}_{2} \mathrm{PO}_{4}-1.0$; $\mathrm{MgSO}_{4} \cdot 7 \mathrm{H}_{2} \mathrm{O}-0.5 ; \mathrm{KCl}-0.5 ; \mathrm{FeSO}_{4} \cdot 7 \mathrm{H}_{2} \mathrm{O}-$ $0.015 ; \mathrm{pH} 5.0$, at temperatures of 16 and $28^{\circ} \mathrm{C}$, with a rotation speed of $220 \mathrm{rpm}$, cultivation time is 9 days.

At the end of fermentation, the biomass was separated by centrifugation at $5000 \mathrm{~g}$ for $30 \mathrm{~min}$. Enzymatic activities were determined in the culture liquid supernatant.

When determining the activity of glycosidases, the following nitrophenyl derivatives of carbohydrates (Sigma-Aldrich, USA) were used as substrates: $p$-nitrophenyl- $\beta$-D-galactopyranoside, $p$-nitrophenyl- $\beta$-D-glucuronide, $p$-nitrophenyl- $\alpha$-D-mannopyranoside, $p$-nitrophenyl- $\alpha$-D-xylopyranoside, $p$-nitrophenyl- $\alpha$-D-fucopyranoside, $p$-nitrophenyl- $\beta$-D-xylopyranoside, $p$-nitrophenyl- $\beta$ - $\mathrm{D}$-glucopyranoside, $p$-nitrophenyl-N-acetyl- $\beta$-D-glucosaminide, $p$-nitrophenyl-N-acetyl- $\alpha$-D-glucosaminide, $p$-nitrophenyl-N-acetyl- $\beta$-D-galactosaminide, $p$-nitrophenyl$\alpha$-D-glucopyranoside, $p$-nitrophenyl- $\alpha$-L-rhamnopyranoside.

To determine the activity of glycosidases, $0.2 \mathrm{~mL}$ of $0.1 \mathrm{M}$ phosphate-citrate buffer (PCB) pH 5.2 and $0.1 \mathrm{~mL}$ of a $0.01 \mathrm{M}$ solution of the corresponding substrate in PCB were added to $0.1 \mathrm{~mL}$ of the culture liquid supernatant. The reaction mixture was incubated for $10 \mathrm{~min}$ at $37^{\circ} \mathrm{C}$. The reaction was stopped by adding $2 \mathrm{~mL}$ of $1 \mathrm{M}$ sodium bicarbonate solution. The same components were added to the control sample, however, in reverse order. The amount of $p$-nitrophenol, which is formed as a result of hydrolysis, was determined by the colorimetric method by the absorption at $400 \mathrm{~nm}$. The unit of activity of the studied glycosidases was taken to be such an amount that hydrolyzes $1 \mu \mathrm{mol}$ of the corresponding substrate for 1 min under experimental conditions [12]. 
The Davis method was used to determine $\alpha$-Lrhamnosidase activity using natural substrates naringin, neohesperidin, and rutin [13]. To determine the activity, $1 \mathrm{ml}$ of $0.05 \%$ natural substrate in $0.1 \mathrm{M}$ PCB pH 5.2 was added to $1 \mathrm{~mL}$ of the enzyme preparation solution. The reaction mixture was incubated for $60 \mathrm{~min}$ at $37^{\circ} \mathrm{C}$. Aliquots of $0.2 \mathrm{~mL}$ were taken; $10 \mathrm{~mL}$ of diethylene glycol, $0.2 \mathrm{~mL}$ of $4 \mathrm{M} \mathrm{NaOH}$ were added. The mixture was kept at room temperature for $10 \mathrm{~min}$, and the color intensity was measured on a spectrophotometer at $420 \mathrm{~nm}$.

The unit of enzyme activity was taken as such an amount that hydrolyzes $1 \mu \mathrm{mol}$ of the substrate in 1 min under the experimental conditions. Specific activity was calculated as the number of activity units (U) per $1 \mathrm{mg}$ of protein.

Protein concentration was determined by the Lowry method [14]. A calibration curve was constructed using bovine serum albumin as a standard.

To obtain a partially purified enzyme preparation, dry ammonium sulfate was added to the culture liquid to a concentration of $90 \%$ saturation under $\mathrm{pH}$ control $(\sim 6.0)$. The mixture was kept for 10-12 $\mathrm{h}$ at a temperature of $4{ }^{\circ} \mathrm{C}$, centrifuged at $5000 \mathrm{~g}$ for $30 \mathrm{~min}$. The precipitate obtained from the fractionation with ammonium sulfate was dialyzed. The study of the effect of temperature on the enzymatic activity was carried out in the range from 4 to $60{ }^{\circ} \mathrm{C}$ and $\mathrm{pH}$ values from 2.0 to 9.0 , the latter was created using 0.01 M PCB.
All experiments were carried out in at least 3-5 replicates. Statistical processing of the results of the experimental series was carried out by standard methods using the Student's t-test at a $5 \%$ significance level [15].

Results. To identify glycosidase activities in the culture liquid supernatant, the $P$. mandelii U1 culture was grown on a synthetic medium in which rhamnose was used as carbon and sodium nitrate was used as nitrogen. The study of enzymatic activities in the dynamics of growth indicates that already on the third day of cultivation in the supernatant of the culture liquid of $P$. mandelii U1, $\alpha$-L-rhamnosidase activity $(0.09 \mathrm{U} / \mathrm{mg}$ protein) was noted (Fig. 1). On the fifth day of cultivation, in addition to $\alpha$-L-rhamnosidase $(0.09 \mathrm{U} / \mathrm{mg}$ protein), $\beta$-D-glucosidase $(0.09 \mathrm{U} / \mathrm{mg}$ protein) and $\alpha$-D-glucosidase $(0.09 \mathrm{U} / \mathrm{mg}$ protein) activities were identified. On the seventh and ninth days of cultivation, the spectrum of glycosidase activities was wider, except for $\alpha$-L-rhamnosidase ( 0.2 and $0.16 \mathrm{U} / \mathrm{mg}$ protein, respectively), $\beta$-D-glucosidase (0.02 and $0.05 \mathrm{U} / \mathrm{mg}$ protein, respectively) and $\alpha$-D-glucosidase $(0.04$ and $0.08 \mathrm{U} / \mathrm{mg}$ protein, respectively), $\alpha$-D-mannosidase $(0.025$ and $0.025 \mathrm{U} / \mathrm{mg}$ protein, respectively), $\alpha$-D-fucosidase (0.025 and $0.05 \mathrm{U} / \mathrm{mg}$ protein, respectively), $\beta$-Dglucosaminidase $(0.025$ and $0.025 \mathrm{U} / \mathrm{mg}$ protein, respectively) and $\beta$-D-galactosaminidase $(0.025$ and $0.025 \mathrm{U} / \mathrm{mg}$ protein, respectively).

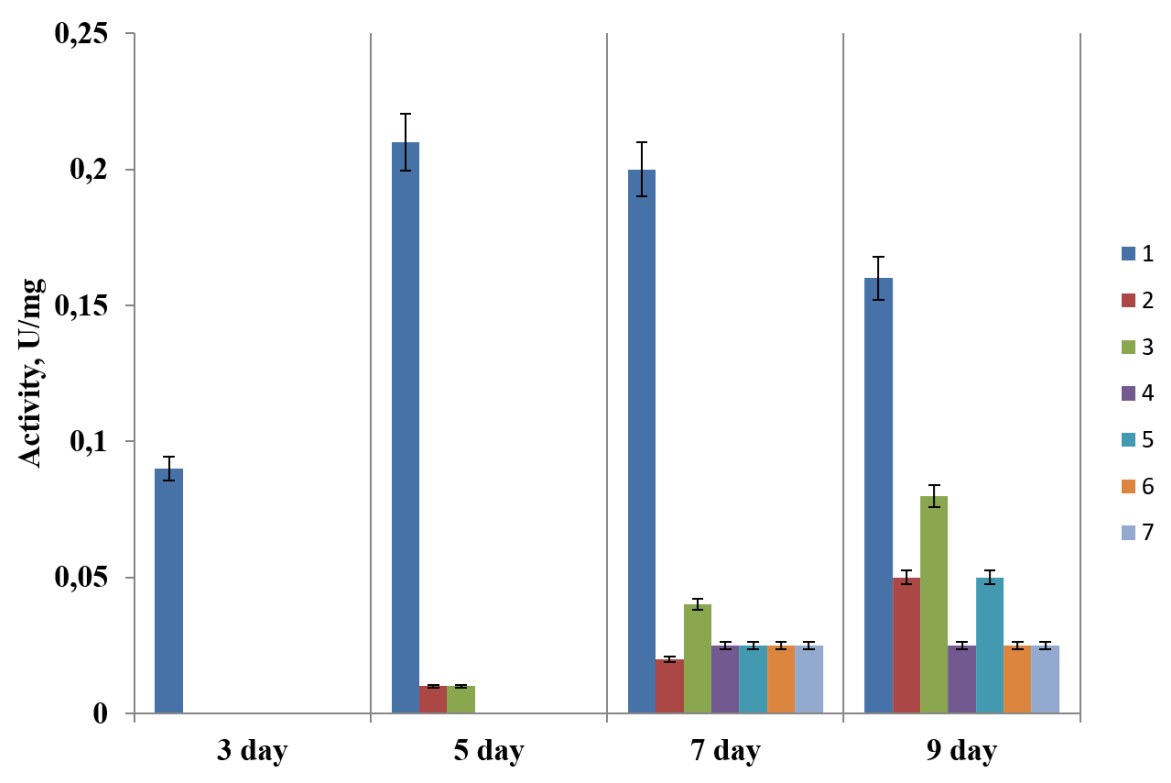

F i g. 1. Dynamics of enzymatic activities of $P$. mandelii $\mathrm{U} 1 \mathrm{~d}$ during cultivation on the following substrates: $p$-nitrophenyl- $\alpha$-L-rhamnopyranoside (1), $p$-nitrophenyl- $\beta$-D-glucopyranoside (2), $p$-nitrophenyl- $\alpha$-D-glucopyranoside (3), p-nitrophenyl- $\alpha$-D-mannopyranoside (4), $p$-nitrophenyl- $\alpha$-D-fucopyranoside (5), $p$-nitrophenyl-N-acetyl- $\beta$-D-glucosaminide (6), $p$-nitrophenyl-N-acetyl- $\beta$-D-galactosaminide (7) 
Since among the studied glycosidase activities, $\alpha$-L-rhamnosidase was the highest, subsequent studies were aimed at investigating its properties. Thus, the study of the influence of the growing temperature showed (Fig. 2) that the temperature of $16{ }^{\circ} \mathrm{C}$ is more optimal for the synthesis of $\alpha$-L-rhamnosidase from $P$. mandelii $\mathrm{U} 1$ than $28{ }^{\circ} \mathrm{C}$, at which the enzyme biosynthesis decreased. The study of the dynamics of the synthesis of $\alpha$-L-rhamnosidase activity by the P. mandelii U1 culture showed (Fig. 2) that the maximum enzymatic activity is observed on the $5^{\text {th }}$ day of cultivation when grown at $16^{\circ} \mathrm{C}$.

Further studies of the properties were carried out on a partially purified preparation of $\alpha$-Lrhamnosidase.

When studying the effect of $\mathrm{pH}$ on the rate of hydrolysis of naringin, it was found that the optimum action of $P$. mandelii $\mathrm{U} 1 \alpha-\mathrm{L}-$ rhamnosidase is at $\mathrm{pH} 5.0$ (Fig. 3).

Typically, the rate of reaction that enzymes catalyze increases to an optimal value as the temperature rises to the point at which the enzyme is inactivated. The study of the optimal temperature in the temperature range from 4 to $60{ }^{\circ} \mathrm{C}$ showed that at $4{ }^{\circ} \mathrm{C}$ the $\alpha$-L-rhamnosidase activity of P. mandelii $\mathrm{U} 1$ was the highest (Fig. 4). With an increase in temperature, the $\alpha$-L-rhamnosidase activity of $P$. mandelii $\mathrm{U} 1$ decreased: by $25 \%$ at $15{ }^{\circ} \mathrm{C}$, by $70 \%$ at $50{ }^{\circ} \mathrm{C}$. Complete inactivation of the enzyme was observed at $60{ }^{\circ} \mathrm{C}$.

Studies of the substrate specificity of $P$. mandelii U1 enzyme preparation were carried out both on synthetic $p$-nitrophenyl derivatives of monosaccharides and on natural flavonoids such as naringin, neohesperidin, and rutin. P. mandelii enzyme preparation exhibited higher activity on

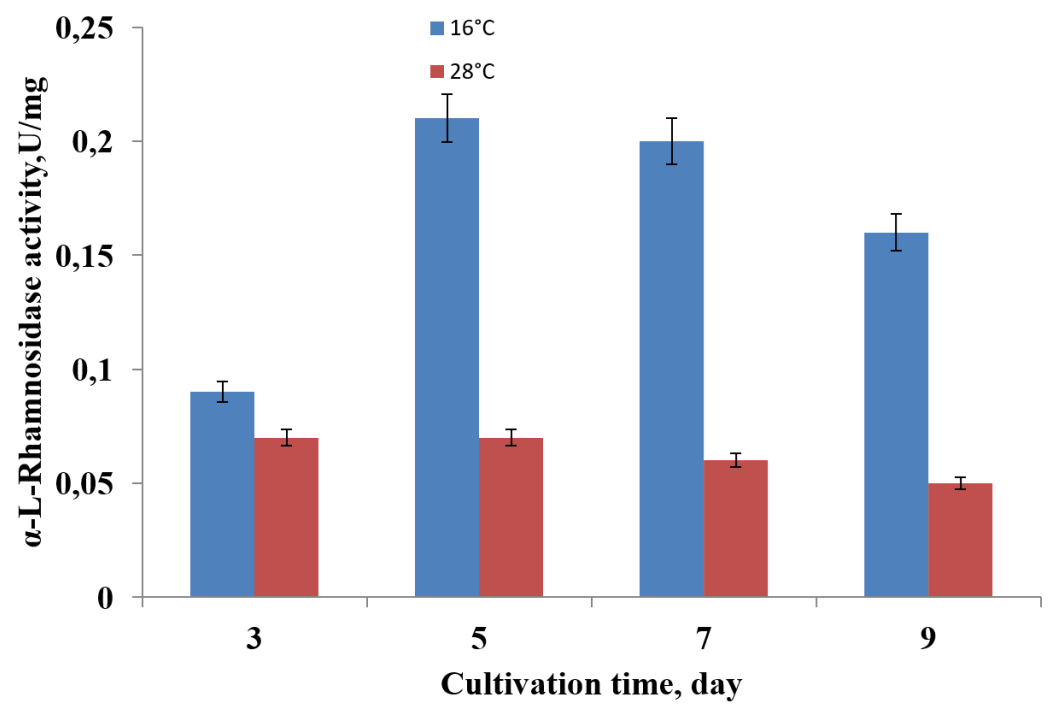

F i g. 2. Dynamics of the synthesis of $P$. mandelii $\mathrm{U} 1 \alpha$-L-rhamnosidase at different temperatures

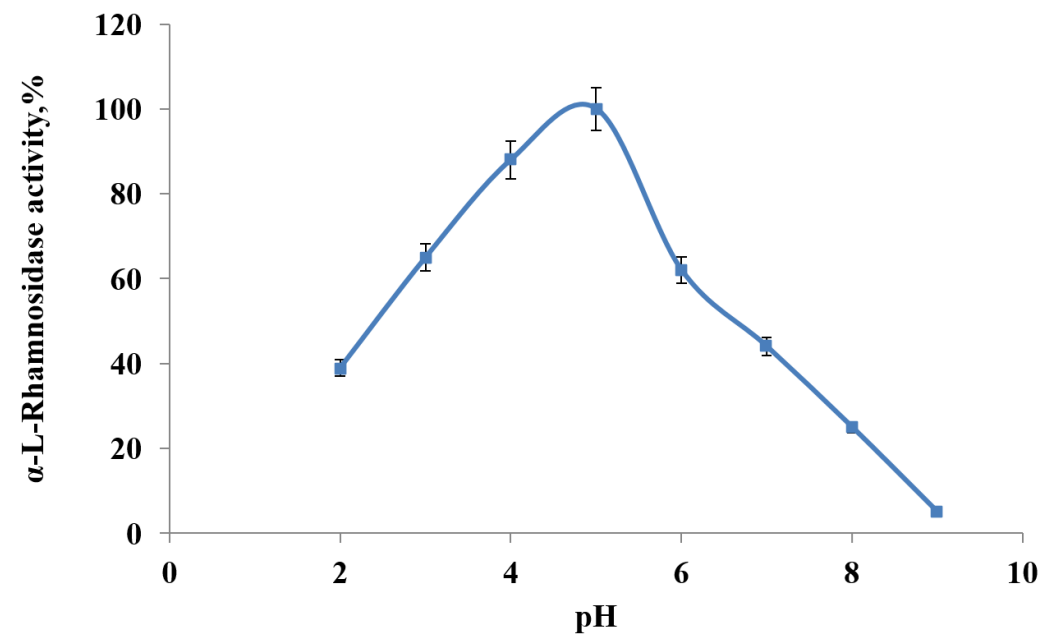

F i g. 3. Effects of $\mathrm{pH}$ on $\alpha$-L-rhamnosidase activity of $P$. mandelii $\mathrm{U} 1\left(37^{\circ} \mathrm{C}\right)$ 
natural substrates rutin $(0.26 \mathrm{U} / \mathrm{mg}$ protein $)$, naringin $(0.18 \mathrm{U} / \mathrm{mg}$ protein $)$, and neohesperidin $(0.14 \mathrm{U} / \mathrm{mg}$ protein) than on synthetic. So, on $p$-nitrophenyl- $\alpha$ L-rhamnopyranoside it was $0.11 \mathrm{U} / \mathrm{mg}$ protein, on $p$-nitrophenyl- $\beta$-D-glucopyranoside $-0.075 \mathrm{U} / \mathrm{mg}$ protein, on $p$-nitrophenyl- $\alpha$-D-glucopyranoside $0,08 \mathrm{U} / \mathrm{mg}$ protein, on $p$-nitrophenyl- $\alpha-\mathrm{D}$-mannopyranoside $-0.075 \mathrm{U} / \mathrm{mg}$ protein (Fig. 5).

Thus, it was shown that the temperature optimum of $\alpha$-L-rhamnosidase preparation from $P$. mandelii, isolated from moss in Antarctica, Galindez Island, is $4{ }^{\circ} \mathrm{C}$, the optimum $\mathrm{pH}$ is 5.0 , the enzyme is able to hydrolyze as synthetic substrates $p$-nitrophenyl- $\alpha$-L-rhamnopyranoside, $p$-nitrophenyl- $\beta$-D-glucopyranoside, $p$-nitrophenyl$\alpha$-D-glucopyranoside, $p$-nitrophenyl- $\alpha$-D-mannopyranoside, and natural substrates - naringin, neohesperidin, and rutin, which suggests the possibility of its use in the future in food technologies.
Discussion. Psychrophilic organisms that constantly live in cold environments have developed many adaptations that have allowed them to thrive in cold environments. A key feature of these devices is the ability to synthesize enzymes, which at low and moderate temperatures are much more active than their mesophilic and thermophilic analogies. Their high specific activity is undoubtedly associated with structural modifications that can be located at a great distance from the active site and which usually lead to higher thermal instability of these enzymes, often associated with even faster thermal inactivation. The unique properties of these enzymes are also due to the fact that their structure contains fewer disulfide bridges and proline residues, but higher contents of glycine residues, as well as an increased formation of loop structures [16].

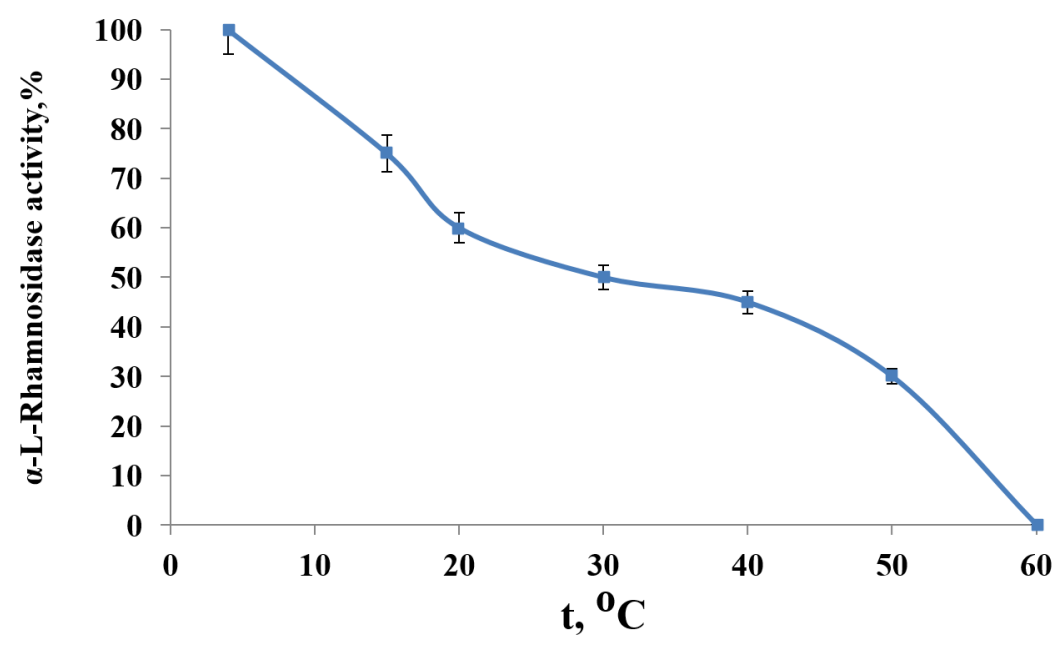

F i g. 4. Effects of temperature on the P. mandelii $\mathrm{U} 1 \alpha$-L-rhamnosidase activity (pH 5.0)

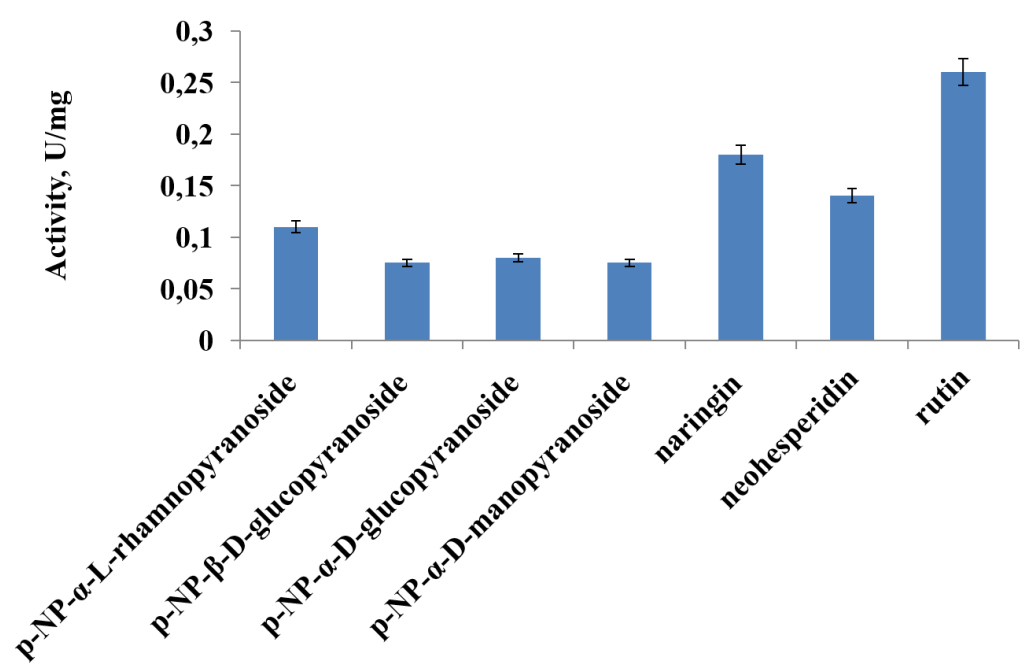

F i g. 5. Substrate specificity of $P$. mandelii U1 enzyme preparation 
Bacterial $\alpha$-L-rhamnosidases are poorly characterized, but their biochemical properties can be of great importance for processes in which fungal $\alpha$-L-rhamnosidases cannot be used. One of the factors that increase the rate of the enzymatic reaction is temperature. Unfortunately, in the scientific literature there are practically no data on $\alpha$-L-rhamnosidase activities at temperatures below $20{ }^{\circ} \mathrm{C}$, since the temperature optimum for the action of most $\alpha$-L-rhamnosidases is 40 $60{ }^{\circ} \mathrm{C}$. Thus, the temperature optimum of $005 \mathrm{NJ}$ isolate with $\alpha$-L-rhamnosidase activity was $40{ }^{\circ} \mathrm{C}$ [17]. Similar values were recorded for $\alpha$-L-rhamnosidases from Pichia angusta and Absidia sp. 39 [18.19]. Researchers have shown that the $\alpha$-Lrhamnosidase from Absidia sp. showed only $40 \%$ activity at $20^{\circ} \mathrm{C}$ [19]. At the same time, the authors [18] indicated that Pseudoalteromonas sp. 005NJ exhibited $\alpha$-L-rhamnosidase activity at $4{ }^{\circ} \mathrm{C}$. It showed a specific growth rate of $0.12-0.19 \mathrm{~h}^{-1}$ in the temperature range from -1 to $8{ }^{\circ} \mathrm{C}$. Optimum $\mathrm{pH}$ and temperature values were 6 and $40{ }^{\circ} \mathrm{C}$, respectively. At $7{ }^{\circ} \mathrm{C}, 005 \mathrm{NJ}$ isolate retained only $19 \%$ of $\alpha$-L-rhamnosidase activity, and at $4{ }^{\circ} \mathrm{C}$, the activity of $005 \mathrm{NJ}$ isolate decreased to $6 \%$. Similar data are shown for the Pseudoalteromonas sp. [18]. In our study, it was shown that a temperature of $4{ }^{\circ} \mathrm{C}$ is optimal for the action of $P$. mandelii enzyme preparation. It was also shown that when grown at $16{ }^{\circ} \mathrm{C}$, a higher $\alpha$-L-rhamnosidase activity was observed than at $28^{\circ} \mathrm{C}$. Perhaps this is due to the fact that P. mandelii strain was isolated at $5{ }^{\circ} \mathrm{C}$; therefore, lower temperatures increase the activity of the studied culture. We found that the $\alpha$-Lrhamnosidase activity of the studied $P$. mandelii strain at $4{ }^{\circ} \mathrm{C}$ was the highest.

Optimal $\mathrm{pH}$ values are among the important characteristics of enzyme preparations. It is known that $\alpha$-L-rhamnosidases have a $\mathrm{pH}$ optimum of 2.0 to 11.0. The main differences between fungal and bacterial enzymes are significant differences in the $\mathrm{pH}$ of the action. Fungal enzymes exhibit a $\mathrm{pH}$ optimum in the acidic range of 4.0 to 6.0 , while bacterial ones are close to neutral or alkaline. These properties predetermine the use of fungal and bacterial enzymes in different areas. Thus, fungal $\alpha$-L-rhamnosidases are more used in such processes as the production of wines [18] and juices [19]. Bacterial enzymes are mainly used in the production of L-rhamnose by hydrolysis of hesperidin and various flavonoid glycosides [18].

The results obtained when studying the optimal $\mathrm{pH}$ values on a partially purified enzyme preparation of $P$. mandelii indicate that the optimum
$\mathrm{pH}$ of its action is 5.0, i. e. it is in the range of action of the $\mathrm{pH}$ of fungal $\alpha$-L-rhamnosidases. The $\alpha$-L-rhamnosidase activity of isolate $005 \mathrm{NJ}$ was optimal at $\mathrm{pH} 6$, but was inactive at acidic $\mathrm{pH}$ values. Sensitivity to low $\mathrm{pH}$ values can be a limiting factor in the industrial use of enzymes in food processing.

Studies of the substrate specificity showed that P. mandelii enzyme preparation displayed higher activity on natural than on synthetic substrates. This specificity is found in many bacterial $\alpha$-Lrhamnosidases $[18,19]$.

Microbial cold-active enzymes from various sources can be used in a wide variety of processes where low temperatures are required [19]. Thus, they can find application as additives in detergents used for cold washing, and as additives in the food industry during fermentation, cheese production, baked goods and meat softening, in the manufacture of food products, reagents for molecular biology, antibiotics, in cosmetics and some other types of products. Another advantage of cold-active enzymes, especially from a food industry point of view, is the prevention of bacterial contamination that can occur when used at high temperatures in production [20].

The importance of finding new producers of cold-active enzymes is confirmed by the fact that currently the annual market for thermotolerant enzymes is already 520 million dollars. As for fundamental research, the study of the properties of enzymes of psychrophilic microorganisms will provide information on the mechanisms of their adaptation to functioning at low temperatures.

Conclusions. The temperature optimum of P. mandelii U1 $\alpha$-L-rhamnosidase preparation isolated from moss in Antarctica, Galindez Island, is $4{ }^{\circ} \mathrm{C}$, the optimum $\mathrm{pH}$ is 5.0 , the enzyme is able to hydrolyze as synthetic substrates p-nitrophenyl- $\alpha$-L-rhamnopyranoside, $p$-nitrophenyl- $\beta$-D-glucopyranoside, p-nitrophenyl- $\alpha$ D-glucopyranoside, $p$-nitrophenyl- $\alpha$-D-mannopyranoside, and natural substrates - naringin, neohesperidin and rutin, which suggests the possibility of its use in the future in food technologies, in particular in food processing and waste degradation at low temperatures.

Acknowledgements. The authors are sincerely grateful to PhD G.V. Gladka and prof. O.B. Tashyrev for provided to us the culture of Pseudomonas mandelii U1 for research (Department of Extremophilic Microorganisms of the Zabolotny Institute 
of Microbiology and Virology, National Academy of Sciences of Ukraine).

\section{a-L-РАМНОЗИДАЗНА АКТИВ- НІСТЬ АНТАРКТИЧНОГО ШТАМУ PSEUDOMONAS MANDELII U1}

\section{О.В. Гудзенко, Н.В. Борзова, Л.Д. Варбанець}

Інститут мікробіології і вірусології ім. Д.К. Заболотного НАН Украӥни, вул. Академіка Заболотного, 154, Київ, 03143, Украӥна

$$
\text { Р е } 3 \text { ю м е }
$$

В останні роки адаптовані до холоду ферменти все частіше використовуються в таких промислових процесах, як харчова, текстильна промисловості, виробництво напоїв. Більш того, холодоактивні ферменти зазвичай термолабільні і можуть бути інактивовані при незначному нагріванні. Це особливо важливо в реакціях, коли необхідно інактивувати фермент після того, як він виконав свою функцію, при зберіганні умов, які дозволяють функціонування інших ферментів, що беруть участь у реакції. Серед таких ензимів важливу роль відіграють глікозидази, які застосовуються в медико-технологічних процесах, харчовій промисловості, біотехнологіях очистки та переробки сировини, а також у багатьох інших сферах діяльності людини. Тому метою роботи було дослідити здатність психротолерантної бактерії Pseudomonas mandelii $\mathrm{U} 1$ продукувати глікозидази, зокрема $\alpha$-Lрамнозидазу, а також дослідити їхні фізико-хімічні властивості та субстратну специфічність. Методи. Глікозидазні активності визначали методами Romero i Davis, білок - методом Lowry. Результати. Вивчення ферментативної активності в динаміці свідчить про те, що вже на третю добу культивування в супернатанті культуральної рідини

1. Cary SC, McDonald IR, Barrett JE, Cowan DA. On the rocks: the microbiology of Antarctic dry valley soils. Nat Rev Microbiol 2010; 8:129138. doi:10.1038/nrmicro2281

2. Wang NF, Zhang T, Zhang F, et al. Diversity and structure of soil bacterial communities in the Fildes Region (maritime Antarctica) as revealed by 454 pyrosequencing. Front Microbiol. 2015; 6:1188. doi:10.3389/fmicb.2015.01188

3. Cowan DA, Tow LA. Endangered Antarctic environments. Ann Rev Microbiol. 2004; 58:649-690.
P. mandelii U1 відмічали активність $\alpha$-L-рамнозидази (0.09 Од/мг білка). На п'яту добу культивування, крім $\alpha$-L-рамнозидази (0.09 Од/мг білка), була ідентифікована активність $\beta$-D-глюкозидази (0.09 Од/мг білка) і $\alpha$-D-глюкозидази (0.09 Од/ мг білка). На сьому і дев'яту добу культивування спектр активності глікозидаз був більш широким: окрім $\alpha$-L-рамнозидази (0.2 і 0.16 Од/мг білка відповідно), $\beta$-D-глюкозидази (0.02 і 0.05 Од/мг білка відповідно) і $\alpha$-D-глюкозидази (0.04 і 0.08 Од/мг білка відповідно), були виявлені $\alpha$-D-маннозидаза (0.025 Од/мг і 0.025 Од/мг білка відповідно), $\alpha$-Dфукозидаза (0.025 і 0.05 Од/мг білка відповідно), $\mathrm{N}$-ацетил- $\beta$-D-глюкозамінідаза (0.025 Од/мг i 0.025 Од/мг білка відповідно) та $\mathrm{N}$-ацетил- $\beta$ D-галактозамінідаза $(0.025$ Од/мг і 0.025 Од/ мг білка відповідно). Оскільки активність $\alpha$-Lрамнозидази була найбільш високою, наступні дослідження були спрямовані на вивчення іiї властивостей. Було показано, що $\alpha$-L-рамнозидаза

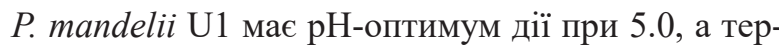
мооптимум - при $4{ }^{\circ} \mathrm{C}$. Висновки. Препарат $\alpha$-Lрамнозидази $P$. mandelii $\mathrm{U} 1$, який був ізольований із моху в Антарктиці (о. Галіндез), проявляе термооптимум при $4{ }^{\circ} \mathrm{C}$, оптимальне значення $\mathrm{pH}$ складає 5.0, ферментний препарат здатний гідролізувати як синтетичні субстрати $n$-нітрофеніл$\alpha$-L-рамнопіранозид, $n$-нітрофеніл- $\beta$-D-глюкопіранозид, $n$-нітрофеніл- $\alpha-\mathrm{D}$-глюкопіранозид, $n$-нітрофеніл- $\alpha$-D-манопіранозид, так і природні субстрати - нарінгин, неогесперидини та рутин, що дозволяє припустити можливість його застосування у майбутньому в харчових технологіях, зокрема, в процесах переробки харчових продуктів та деградації відходів за низьких температур.

Ключові слова: Pseudomonas mandelii U1, $\alpha$-Lрамнозидаза, фізико-хімічні властивості, субстратна специфічність.

doi:10.1146/annurev.micro.57.030502.090811

4. Niederberger TD, Sohm JA, Gunderson TE, et al. Microbial community composition of transiently wetted Antarctic dry valley soils. Front Microbiol 2015; 6:9. doi:10.3389/fmicb.2015.00009

5. Lee YM, Yang JY, Baek K, et al. Pseudorhodobacter psychrotolerans sp. nov., a psychrotolerant bacterium isolated from terrestrial soil, and emended description of the genus Pseudorhodobacter. Int J Syst Evol Microbiol 2016; 66:10681073. doi:10.1099/ijsem.0.000841 
6. Fenice M. The Psychrotolerant Antarctic Fungus Lecanicillium muscarium CCFEE 5003: a powerful producer of cold-tolerant chitinolytic enzymes. Molecules. 2016; 21:447. doi:10.3390/ molecules 21040447

7. Vasileva-Tonkova E, Romanovskaya V, Gladka G, et al. Ecophysiological properties of cultivable heterotrophic bacteria and yeasts dominating in phytocenoses of Galindez Island, maritime Antarctica. World J Microbiol Biotechnol. 2014; 30:1387-1398. doi:10.1007/s11274-013-1555-2

8. Pereira JQ, Lopes FC, Petry MV. Isolation of three novel Antarctic psychrotolerant feather-degrading bacteria and partial purification of keratinolytic enzyme from Lysobacter sp. A03. International Biodeterioration \& Biodegradation. 2014; 88:1-7. DOI:10.1016/j.ibiod.2013.11.012

9. FelipeVásquez-Ponce, Sebastián HigueraLlantén, María S. Pavlov, Sergio H. Marshall, Jorge Olivares-Pacheco. Phylogenetic MLSA and phenotypic analysis identification of three probable novel Pseudomonas species isolated on King George Island, South Shetland, Antarctica. 2018. Brazilian journal of microbiology. 49 (4):695702. https://doi.org/10.1016/j.bjm.2018.02.005.

10. Brovarskaya OS, Varbanets LD, Gladka GV, German AD, Tashirev OB. Lipopolysaccharide of Pseudomonas mandelii, isolated in Antarctica. Mikrobiol Z. 2021; 83(4):24-34.

11. Chaplin ME, Kennedy JE. Carbohydrate analysis. Oxford: IRLPress, 1986. 228 p.
12. Davis BJ. Assay of naringinase. Anal Biochem. 1985; 149(2):566-571.

13. Lowry OH, Rosebrough NJ, Farr AL, Randall RJ. Protein measurement with folinphenol reagent. J Biol Chem. 1951; 193(2):265-275.

14. Lakyn HF. [Byometryia]. Moscow: Vysshaya Shkola; 1990. Russian.

15. Feller G. Psychrophilic Enzymes: From Folding to Function and Biotechnology. Scientifica (Cairo). 2013: 512840. doi: 10.1155/2013/512840

16. Orrilloa AG, Ledesma P, Delgado OD, Spagna G, Breccia JD. Cold-active $\alpha$-L-rhamnosidase from psychrotolerant bacteria isolated from a sub-Antarctic ecosystem. Enzyme and Microbial Technology. 2007; 40(2):236-241.

17. Yadav V, Yadav PK, Yadav S, Yadav KDS. $\alpha$-LRhamnosidase: A review. Process Biochemistry.2010; 45(8):1226-1235.

18. Manzanares P, Valles S, Ramon D, Orejas M. $\alpha$-L-rhamnosidase: old and new insights. Industrial Enzymes: Springer; 2007. p. 117-140.

19. Maqtari QA, Mahdi AA. Cold-active enzymes and their applications in industrial fields - A review. International Journal of Research in Agricultural Sciences 2019; 6(4):2348-3997.

20. Gobba DC, Tompa G, Otte J. Bioactive peptides from caseins released by cold active proteolytic enzymes from Arsukibacterium ikkense. Food Chemistry. 2014; 165:205-215. 10.1016/j.foodchem.2014.05.082

Received 22.07.2021 